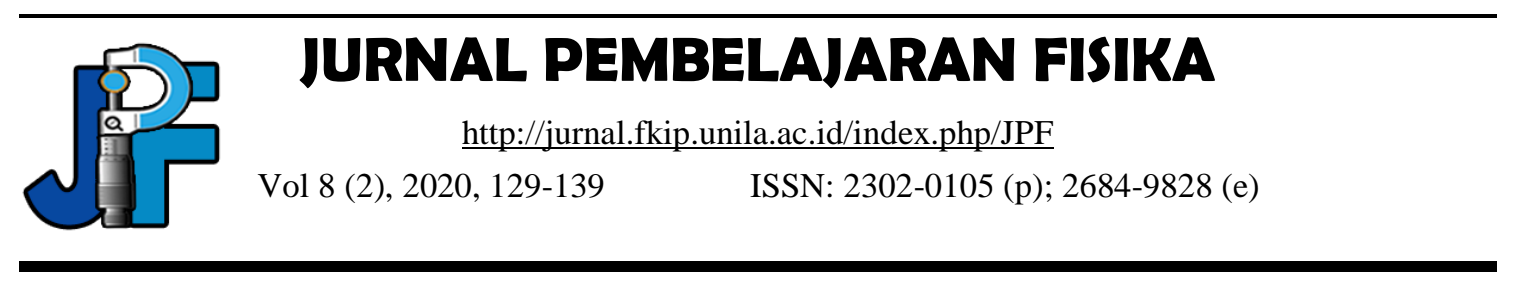

\title{
STEM- Based Multimedia Design for Stimulating HOTS in Theory Bioenergy and Wind Energy: Perception Physics Teacher
}

\author{
Farah Aulia, Agus Suyatna*, Viyanti \\ Physics Education Graduate Program Lampung University, Bandar Lampung, Indonesia \\ *e-mail: asuyatna@yahoo.com
}

\begin{abstract}
The purpose of thiis research is to develop multimedia with the STEM approach to stimulate HOTS on bioenergy and wind energy materials. The research and development (R\&D) method uses the ADDIE design which consists of 5 step, namely: analysis, design, development, implementation, and evaluation. This article will only report the first two stages namely analysis and design. The instrument used was a product needs analysis questionnaire and a practitioner validation sheet using a Likert scale. The data source of the needs analysis phase is high school students and physics teachers in Lampung Province. Product design validation was carried out by professional physics-teacher teachers with a Masters in Physics Education qualification. Where data is collected via Google Form and analyzed using descriptive qualitative. The results showed that multimeEdia to stimulate HOTS on bioenergy and wind energy was needed in the field. Multimedia which has the potential to stimulate HOTS on bioenergy and wind energy materials consists of videos and simulation of bioenergy and wind energy plants that contain all STEM.
\end{abstract}

Keywords: bioenergy, multimedia, stimulating HOTS, STEM, wind energy

DOI: http://dx.doi.org/10.23960/jpf.v8.n2.202001 


\section{INTRODUCTION}

Development in the 21st century requires someone to be proficient in various skills, with the development of education it is expected that students can master these various skills so that they become successful individuals in their lives (Prasetyo 2017). The four pillars of life which include learning to know, learning to do, learning to be, learning to live together are still related to the skills needed in the 21 st century (Scott 2015). The four pillars need to be applied to the learning process such as critical thinking skills, problem solving, metacognition, communication skills, collaboration, innovation, and creation, information literacy, and various other skills. These skills are known as 4C skills (Creative, Critical Thinking, Communicative, and Collaborative) (Anggraeni and Sole 2018). Where 4C skills lead to higher order thinking skills (HOTS) (Saregar, Latifah, and Sari 2016; Diani, R., Asyhari, and Julia 2018).

HOTS is the thinking ability to analyze, examine, organize, diagnose, compare, conclude, evaluate, design, develop, create, whereas according to Anderson and krathwohl. HOTS is the ability to analyze, evaluate and create (Fanani and Kusmaharti 2016). HOTS ability has an important role in the world of education, especially in the physics learning process which discusses physical phenomena in everyday life both real and abstract (Damayanti, Parno, Munfaridah, \& Muhardjito, 2015; Irwandani, Kamil, \& Saraswati, 2019). HOTS requires someone to apply new information or knowledge they already have and manipulate the information to reach possible answers in new situations(Aprilia, Sesunan, and Wayan 2019).

In this 21 st century, all this information is very easy for students to enter. The easy entry of this information requires students to analyze, evaluate, because not all of the information is good so HOTS in abstract physics learning requires a stimulus in learning (Subekti 2018). But in reality, in the field, the observations of the physics learning process have not led to the development of HOTS abilities because only part of the material for class XII semester is partially studied. Educators tend to explain briefly the material which is considered important due to time constraints. One of the materials that has not been explained is Renewable Energy. This is known based on the results of teacher questionnaires, student questionnaires via google form, and the UAS and Try Out (TO) scores which are already HOTS based. To stimulate HOTS ability from the above problems, learning support is needed, one of which is the use of multimedia.

Multimedia is a learning medium that is able to present factual, conceptual, effective and efficient information so that learning is more interesting and able to motivate students because the learning material is not only in the form of text but contains images, audio, video, and animation so multimedia-based learning is very helpful in abstract (Susanto and Suyatna 2015), (Gunawan, , Harjono, \& Sutrio, 2017; Rante, Sudarto, \& Ihsan, 2013).

To create multimedia that is able to stimulate HOTS, it must be in accordance with existing needs in the(Sihaloho, Rosidin, and Suyatna 8AD; Puspitasari, Herlina, and Suyatna 2020; P and Williaam 2018) field. Knowing the needs of physics learning in the field requires a needs analysis aimed at students and teachers of physics subjects, for that there is a need for research to determine the need for multimedia to stimulate HOTS in accordance with the needs of educators and students interpreted in the form of multimedia designs that are able to stimulate HOTS . In addition to the use of multimedia, current 
physics learning needs to involve the use of technology and precision in designing physics products known as STEM -based (P and Williaam 2018; Puspitasari, Herlina, and Suyatna 2020; Sihaloho, Rosidin, and Suyatna 2020).

Science, Technology, Engineering, and Mathematic (STEM) is a combined approach of science, technology, engineering, and mathematics and fits 21 st century skills. Based on this, researchers will design multimedia to stimulate HOTS with a STEM approach on Bioenergy and Wind Energy materials.

\section{METHOD}

The research method used in this research and development is the Research and Development $(\mathrm{R} \& \mathrm{D})$ method with a research design based on the ADDIE development model ( analysis, design, development, implementation ,and evaluation) (Serevina and Sari 2018; Hayati, Budi, and Handoko 2015). However, this article reports some of the stages of multimedia development through to the design stage.

\section{Analysis}

The research conducted was obtained from distributing product needs analysis questionnaires to 43 students and 32 educators in physics subjects in Lampung Province via google form. Needs analysis was carried out to obtain information about real conditions in the learning process which consisted of 30 questions for educators and 25 questions for students. The data obtained were analyzed quantitatively descriptively using the percentage technique.

\section{Design}

The design stage is carried out with a practitioner validation sheet using a Likert scale with a selection, namely (1) strongly disagree, (2) disagree, (3) quite agree, (4) agree, (5) totally agree given to the product design validator which consists of 14 professional physics educators with the qualification of Master of Physics Education. A multimedia design in the form of tables, story boards and charts is attached to the assessment instrument . The design assessment instrument is provided in the form of a google form . The feasibility interpretation test is listed in table 1 below:

Table 1. Assessment and Decision Score

\begin{tabular}{cc}
\hline $\begin{array}{c}\text { Average } \\
\text { Score }\end{array}$ & Decision \\
\hline $4,20-5,00$ & Very suitable for stimulating HOTS \\
$3,40-4,19$ & Suitable for stimulating HOTS \\
$2,60-3,39$ & Enough suitable for stimulating HOTS \\
$1,80-2,59$ & Less suitable for stimulating HOTS \\
$1,00-1,79$ & Not suitable for stimulating HOTS \\
\hline
\end{tabular}




\section{RESULT AND DISCUSSION}

Based on the research that has been carried out at the analysis stage, the results of the needs analysis are obtained as follows:

Table 2. Results of the educator's need analysis

\begin{tabular}{|c|c|}
\hline No & Statement Analysis \\
\hline 1. & $93,8 \%$ of Educators have implemented the K 13 revision in schools. \\
\hline 2. & $87,5 \%$ Educators provide questions that contain higher-order thinking skills. \\
\hline 3. & $\begin{array}{l}87,6 \% \text { Educators provide opportunities for students to find information with friends when } \\
\text { discussing. }\end{array}$ \\
\hline 4. & $90,7 \%$ Educators give students the opportunity to exchange ideas and discuss them. \\
\hline 5. & $\begin{array}{l}93,73 \% \text { Educators give students the opportunity to analysis the problems given during } \\
\text { learning. }\end{array}$ \\
\hline 6. & $\begin{array}{l}90,8 \% \text { Educators give students the opportunity to look for other sources in improving } \\
\text { students' critical thinking ability. }\end{array}$ \\
\hline 7. & $\begin{array}{l}90,6 \% \text { Educators give students the opportunity to communicate Physics material being } \\
\text { studied. }\end{array}$ \\
\hline 8. & $90,6 \%$ Educators give students the opportunity to solve problems in their own way. \\
\hline 9. & $93,8 \%$ Educators give students the opportunity to carry out experiments. \\
\hline 10 & $\begin{array}{l}87,5 \% \text { Educators give students the opportunity to display the results of their experiments in } \\
\text { class. }\end{array}$ \\
\hline 11 & $\begin{array}{l}96,9 \% \text { Educators give students the opportunity to complete experiments with the concept of } \\
\text { physics. }\end{array}$ \\
\hline 12 & $94,9 \%$ Educators use a scientific approach to learning. \\
\hline 13 & 96,9\% Educators use media in learning. \\
\hline 14 & 96,9\% Educators apply fun physics learning. \\
\hline 15 & $72,2 \%$ Educators already have multimedia based learning resource infrastructure. \\
\hline 16 & 90,6\% Educators have heard about multimedia based learning resources. \\
\hline 17 & 90,6\% Educators have used the STEM learning approach. \\
\hline 18 & $\begin{array}{l}37,5 \% \text { Educators have developed multimedia learning resources with the STEM approach } \\
\text { to stimulate HOTS. }\end{array}$ \\
\hline 19 & $\begin{array}{l}80,7 \% \text { Educators need multimedia learning resources with the STEM approach to stimulate } \\
\text { HOTS. }\end{array}$ \\
\hline 20 & $\begin{array}{l}84,45 \% \text { Educators are willing to apply multimedia learning resources with the STEM } \\
\text { approach to stimulate HOTS. }\end{array}$ \\
\hline 21 & $\begin{array}{l}81,5 \% \text { Educators hope that multimedia learning resources with a STEM approach are } \\
\text { effective for stimulating HOTS. }\end{array}$ \\
\hline 22 & $\begin{array}{l}87,5 \% \text { Educators hope that multimedia learning resources using the STEM approach can be } \\
\text { used in the learning process. }\end{array}$ \\
\hline 23 & $90,7 \%$ Educators hope that the multimedia makes students interested in learning physics. \\
\hline 24 & $93,8 \%$ Educators are interested in using varied learning resources. \\
\hline 25 & $\begin{array}{l}84,4 \% \text { Educators need multimedia learning resources with an effective STEM approach to } \\
\text { stimulate HOTS. }\end{array}$ \\
\hline 26 & $\begin{array}{l}65.6 \% \text { of teachers feel that they have not conveyed the renewable energy material } \\
\text { completely }\end{array}$ \\
\hline 27 & $84,4 \%$ Educators have yet provided experiments on renewable energy \\
\hline 28 & $83,3 \%$ Educators have not used multimedia when learning about renewable energy materials \\
\hline 29 & $\begin{array}{l}87,5 \% \text { Educators provide questions related to higher-order thinking skills in learning } \\
\text { renewable energy materials }\end{array}$ \\
\hline 30 & 75\% Educators have not stimulated higher-order thinking skills with the STEM approach to \\
\hline
\end{tabular}


Table 3. Results of student's need analysis

\begin{tabular}{|c|c|}
\hline No & Statement Analysis \\
\hline 1. & $67,4 \%$ Students stated that they did not like Physics. \\
\hline 2. & $51,2 \%$ Students state physics is a difficult subject. \\
\hline 3. & $79,1 \%$ Students feel that learning physics is boring. \\
\hline 6. & $48,8 \%$ Students can work on questions that are classified as high-level thinking skills. \\
\hline 7. & $\begin{array}{l}95,3 \% \text { Students are given the opportunity to look for information with friends when } \\
\text { discussing. }\end{array}$ \\
\hline 8. & $97,7 \%$ Students are given the opportunity to exchange ideas and discuss them. \\
\hline 9. & $\begin{array}{l}95,4 \% \text { Students are given the opportunity to analysis the problems given by physics } \\
\text { educators while learning. }\end{array}$ \\
\hline 10. & $\begin{array}{l}97,7 \% \text { Students are given many opportunities by physics educators to look for other } \\
\text { sources. }\end{array}$ \\
\hline 11. & $\begin{array}{l}95,4 \% \text { Students are given the opportunity by physics educators to communicate the } \\
\text { results of the discussion. }\end{array}$ \\
\hline 12. & $\begin{array}{l}83,7 \% \text { Students are given the opportunity by physics educators to solve problems in } \\
\text { their own way. }\end{array}$ \\
\hline 13. & $95,2 \%$ Students are given the opportunity to conduct experiments in physics. \\
\hline 14. & $\begin{array}{l}93 \% \text { Students are given the opportunity by physics educators to display their work } \\
\text { in the classroom. }\end{array}$ \\
\hline 15. & $\begin{array}{l}\text { 93\% Students are given the opportunity by physics educators to complete } \\
\text { experiments using physics concepts. }\end{array}$ \\
\hline 16. & 88,3\% Educators use using less attractive physics learning media \\
\hline 17. & $\begin{array}{l}86 \% \text { of students feel that the teacher has not been maximally doing physics learning } \\
\text { by linking science, technology, engineering and mathematics }\end{array}$ \\
\hline 18. & $\begin{array}{l}86,1 \% \text { The concepts of physics learned can't be applied to Science, Technology, } \\
\text { Engineering, and Mathematical Engineering. }\end{array}$ \\
\hline 19. & $86 \%$ Physics concepts that I learned can be applied in everyday life. \\
\hline 20. & $\begin{array}{l}100 \% \text { Physics learning will be effective when using interesting multimedia learning } \\
\text { resources. }\end{array}$ \\
\hline 21. & $100 \%$ Students are interested in the multimedia used when learning Physics. \\
\hline 22. & $\begin{array}{l}\text { 93\% Students feel confident that learning Physics using multimedia learning } \\
\text { resources will be interesting. }\end{array}$ \\
\hline 23. & $76,7 \%$ Students feel that Static Fluid material is boring. \\
\hline 24. & $\begin{array}{l}97,6 \% \text { Students agree if physics lessons especially renewable energy material is } \\
\text { presented with multimedia learning resources. }\end{array}$ \\
\hline 25. & $\begin{array}{l}88,3 \% \text { Students can understand renewable energy material if using an interesting } \\
\text { multimedia }\end{array}$ \\
\hline
\end{tabular}

Based on the above table we know that most of teacher conduct based learning curriculum in 2013 and has provided about HOTS for learners and educators already know most of the learning approach STEM. However, in the results of the student questionnaire, students felt that they had not carried out learning by maximally linking science, technology, engineering and mathematics learning and understanding the physics concepts that were learned to be applied in everyday.

Teachers yet to develop a multimedia approach to STEM to stimulate HOTS particularly on renewable energy materials, mostly educators claimed to have completed doing the learning on this matter and has not associated experimental renewable energy materials in because of time constraints. Even though most schools have multimedia-based learning infrastructure, and based on a questionnaire the needs of 
educators want to apply multimedia development with the STEM approach to stimulate HOTS in renewable energy materials.

Teacher diagnose that developing effective multimedia approach to stimulate STEM mater HOTS on Bioenergy and wind energy. Based on the student questionnaire it is known that most students do not like physics lessons because they feel physics lessons are difficult and boring because they are not interesting. Students agree and are interested in learning using multimedia learning. Based on the results of the questionnaire analysis of the needs of educators and students, it can be concluded that a valid, effective and practical form of multimedia based on the STEM approach is needed that is able to stimulate student.

Based on the analysis of the results of the students' needs, the next stage is carried out, namely the design stage. At this stage, with designing science research is a design chart of multimedia, multimedia story board and multimedia design tables that are tailored to the needs of educators and learners. Furthermore, the design given to the product design validator consisting of 14 professional educators with the qualification of Masters in Physical Education to be validated. The results of the validation of the STEM based multimedia development design to stimulate HOTS on Bioenergy and wind energy are as follows:

Table 4. Design Validation Results Table

\begin{tabular}{ccccccc}
\hline Category & $\begin{array}{c}\text { Theme } \\
\mathbf{1}\end{array}$ & $\begin{array}{c}\text { Theme } \\
\mathbf{2}\end{array}$ & $\begin{array}{c}\text { Theme } \\
\mathbf{3}\end{array}$ & $\begin{array}{c}\text { Theme } \\
\mathbf{4}\end{array}$ & $\begin{array}{c}\text { Theme } \\
\mathbf{5}\end{array}$ & $\begin{array}{c}\text { Theme } \\
\mathbf{6}\end{array}$ \\
\hline $\begin{array}{c}\text { suitability of features in } \\
\text { content to stimulate HOTS } \\
\text { with the STEM approach }\end{array}$ & 4,46 & 4,54 & 4,48 & 4,93 & 4,5 & 4,6 \\
\hline $\begin{array}{c}\text { Compatibility of content } \\
\text { against STEM components }\end{array}$ & 4,57 & 4,64 & 4,78 & 4,57 & 4,71 & 4,5 \\
\hline $\begin{array}{c}\text { Multimedia form to stimulate } \\
\text { HOTS }\end{array}$ & 4,57 & 4,5 & 4,5 & 4,57 & 4,64 & 4,79 \\
\hline Average & 4,54 & 4,56 & 4,58 & 4,66 & 4,60 & 4,62 \\
\hline
\end{tabular}

Based of the validation result table is known that all the criteria in the average yield of the validator assessment on the range of values from 4.40 to 5.00 where if we look at the table this criteria entered in the category of Very suitable for stimulating HOTS. The results of this validity also received good comments and support/ enthusiasm so that this STEM-based multimedia development could soon be realized to stimulate HOTS. In addition to comments, there are suggestions to give attention to stimulating the ability to generate ideas for designing interactive animations for biogas and wind power plants and their application to the Wind power Plants work system. The results of this study are in line with research (Susanto and Suyatna 2015; Husein, Herayanti, and Gunawan 2015; Chen, Stelzer, and Gladding 2010; Clark and Mayer. 2011) which states that the use of multimedia is effective in improving critical, creative thinking, solving problems and causing meaningful learning. The STEM-based multimedia development design to stimulate HOTS in bioenergy and wind energy materials based on the results of the design validation, a research design chart is drawn up as follows: 


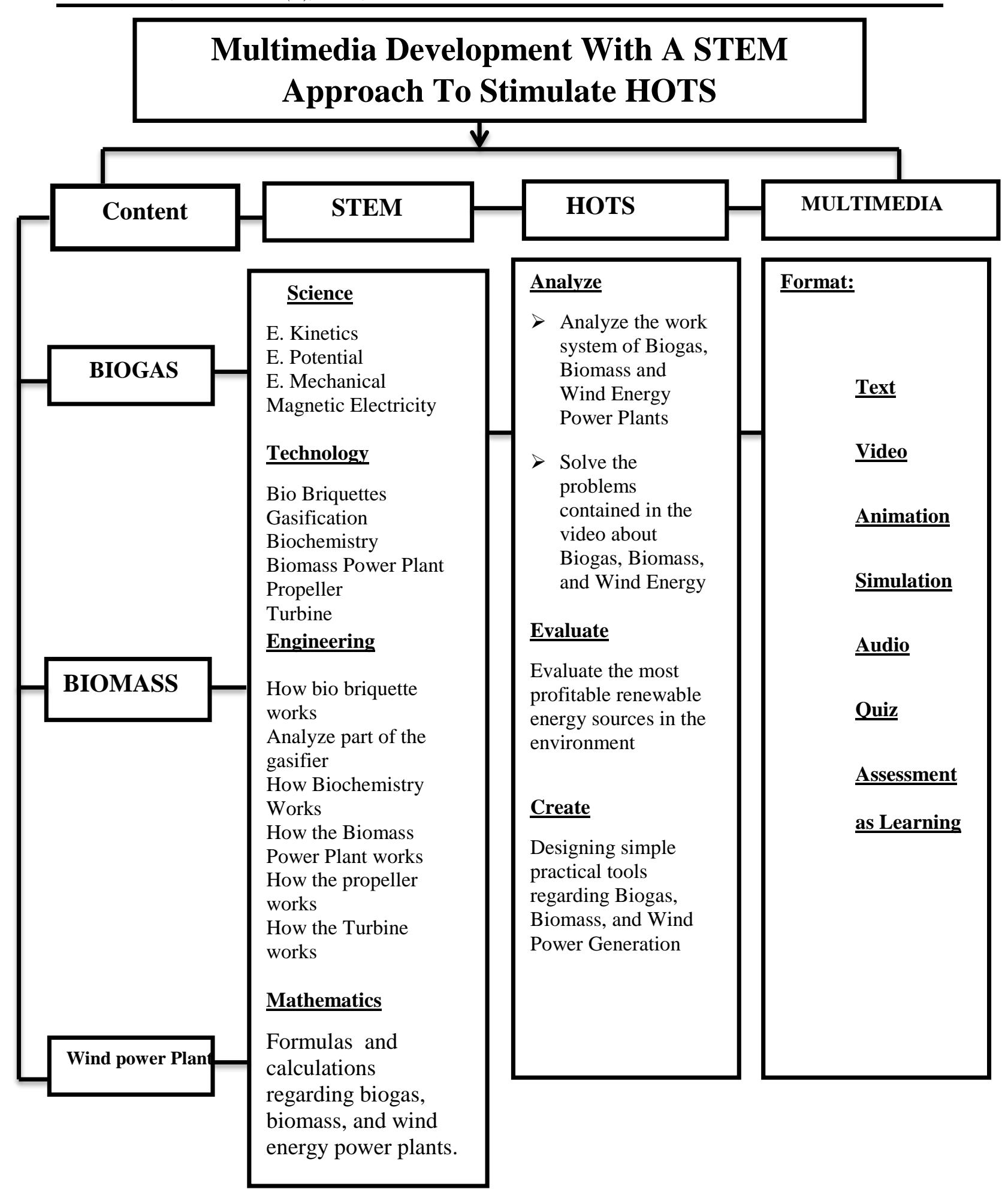

Figure 2. Multimedia Development Design Chart.

From the chart, it is illustrated that the topic of discussion on multimedia is divided into six, namely the concept of energy and renewable energy sources, Biogas power plants, the application of technology from Biogas power plants, Biomass power plants, application of technology from Biomass power plants and wind power plants. In 
the chart it has also been explained that the features used in multimedia are text, images, videos, animations, simulations, and interactive quizzes will be added in it as an evaluation of the learning that has been explained. Each feature explains its relation to STEM and what capabilities will be stimulated so that it can stimulate HOTS. For example, on topic 1 explains the concept of energy and energy sources where on topic 1 facilitates students to analyze energy sources in everyday life. In this video there is an animation that helps group several objects around us that need energy, for example, plants need energy from sunlight for photosynthesis, humans need energy (food) to carry out activities, fans to produce wind or stoves for cooking, so that students realize how important energy is for the life of living things on earth.

In topic 1, there are also different images so that students are able to analyze where the energy sources in daily activities come from, diagnose the types of energy sources used, evaluate which types of energy sources are the most beneficial for everyday life based on pictures and charts which has been presented, and can create concept maps of energy sources based on video, pictures, charts, animations on topics1. Where on topic 1 also integrates with the STEM approach. Science Aspect: Theory of Energy Sources, Renewable Energy, and Renewable Energy. Technological Aspects: solar cells, hydropower, wind power, nuclear power plants, bioenergy. Engineering: Examples of Renewable Energy and Renewable Energy in every day life. Mathematics: Energy equation formulas, Energy conversion.

Topic 2 contains visualization of the application of renewable energy sources, namely biogas. This topic contains videos of technology used in the biogas working system so that we can use electricity in our daily lives, a table of the composition of the ingredients for making biogas, a chart of the process of transforming organic matter, the benefits of biogas from the agricultural, economic, energy and environmental sectors, and factors affecting biogas production. This topic also contains an animation of the biogas work system from grouping the types of waste used after it is made into compost to create a waste / waste treatment plant by applying the concept of chemical elements, chemicals and compounds, namely the fermentation process that is inserted into the slide, assisted by using a generator as a generator of electricity and generating electricity.

On topic 3 contains a visualization of the making of bio briquettes and a narrative explaining the definition, raw materials of bio briquettes, advantages and disadvantages of bio briquettes and the process of making bio briquettes. In the video about making bio briquettes contains a STEM approach. In the field of Science: contains theoretical explanations regarding bio briquettes, In the field of Technology: making bio briquettes, In the field of Engineering: How to make bio briquettes, In the Mathematical field: calculations regarding the rate of pyrolysis, solid fuel combustion formula.

Then on topic 4 contains a visualization of the Biomass simulation (an experiment of electric batteries from lime to produce electricity) and explains the basic theory, tools and materials, practicum procedures regarding electric batteries from lime fruit to generate STEM-based electricity interspersed with charts and question. In the Science section: explanation of the basic theory of the charging process and the discharging process, where at the time of charging electrical energy is converted into energy chemistry and current discharge the chemical energy is converted into electrical energy, electrical current, electrical voltage chemical reaction, depending potential. In the 
technology section: Fruit Batteries, In the Engineering section: How to create fruit batteries, Mathematics: equation of electric current, electric voltage.

Topic 5 contains a visualization of the Biomass animation (utilization of rotten fruit into electrical energy) and explains the basic theory, tools and materials, practicum procedures regarding the use of rotten fruit into STEM-based electrical energy. In the Science section: explanation of the basic theory of the use of rotten fruit into electrical energy, the process of decay. In the technology section: Fruit rot, In the Engineering section: How to use rotten fruit into electrical energy, Mathematical: chemical equations of exposure, energy change, and can stimulate the ability to analyze what fruit can be used for making biomass, analyze what factors are cause rotten fruit can generate electrical energy, evaluate what rotten fruit produces the most electrical energy, inspires to make biomass from rotting fruit to produce electricity.

Furthermore, this last topic contains visualizations of wind power generation videos, namely windmills and turbines, explaining the basic theory, tools and materials, simulating practicum procedures regarding STEM-based windmills and turbines punctuated by several questions about problems that occur in practicum, issues and information about fruit batteries so that students are active, critical, creative and can solve problems. In this topic, we describe how each component in a power plant works, starting from the wind that blows the propeller so that the kinetic energy that enters the generator can cause a potential difference that results in voltage and electric current up to the transformer in an electrical substation that has a high voltage flow to the house. - Low voltage houses in the form of interactive animations interspersed with questions, pictures, text. In the Science section: basic explanation of the theory of wind power generation (windmills produce electricity), magnetic field, electric current, electric voltage, faraday law. In the technology section: Windmills, In the Engineering section: How windmills work into electrical energy, Mathematics: energy, Faraday law.

Multimedia is expected to indirectly make students happy learning physics, stimulate HOTS and apply the STEM approach and effectively help teachers to provide learning media during Distance Learning (PJJ) as in current conditions (Roida and Fitriani Yuni 2020; Ali and Afreni 2020).

\section{CONCLUSION}

The results showed that multimedia to stimulate HOTS about Bioenergy and wind energy is needed in the field as evidenced by the results of the distribution of the introductory questionnaire for teachers and students as seen in the table 2 and 3 where educators have not yet finished delivering Bioenergy and wind energy material due to lack of time problem. Teachers haven't develop multimedia to stimulate HOTS with the STEM approach. Multimedia whit has the potential to stimulate HOTS in Bioenergy and wind energy, consists of videos, stimulation, pictures, quizzes of Bioenergy and wind energy plants that contain all aspects of the STEM approach. This can be seen in the multimedia development chart to stimulate HOTS with the STEM approach.

\section{ACKNOWLEDGEMENTS}

We give appreciation to Directorate of Research and Community Service (DRPM) for funding this research through the acceleratig student thesis research (PTM) and the 
Board for Research and Community Service (LPPM) Lampung University which has Provided facilities.

\section{REFERENCES}

Ali, Sadikin, and Hamidah Afreni. 2020. "Pembelajaran Daring Di Tengah Wabah Covid 19.” Jurnal Ilmiah Pendidikan Biologi 6 (2): 214-24.

Anggraeni, D. M., and F. B Sole. 2018. "E-Learning Moodle, Media Pembelajaran Fisika Abad 21." Jurnal Penelitian Dan Pengkajian Ilmu Pendidikan 3 Saintika 1 (2): $57-69$.

Aprilia, R. D., F. Sesunan, and S Wayan. 2019. "Pengembangan LKS Model Blended Learning Berorientasi HOTS Pada Mata Materi Usaha Dan Energi." Journal of Komodo Science Education 1 (2): 45-49.

Chen, Zhongzhou, Timothy Stelzer, and Gary Gladding. 2010. "Using Multimedia Modules to Better Prepare Students for Introductory Physics Lecture.” Physical Review Special Topics - Physics Education Research 6 (1): 1-5. https://doi.org/10.1103/PhysRevSTPER.6.010108.

Clark, Ruth C., and Richard E. Mayer. 2011. E-Learning Dan the Science of Instruction: Proven Guidlines for Consumers Dan Designers of Multimedia Learning. 3rd editio.

Damayanti, Rika, Parno, Nuril Munfaridah, And Muhardjito. 2015. "Pengaruh Model Problem Based Learning (PBL) Dengan Strategi Mind Mapping Terhadap Prestasi Belajar Siswa(HOTS)." In SEMINAR NASIONAL FISIKA DAN PEMBELAJARANNYA, 13-20.

Diani, R., A. Asyhari, and O. N Julia. 2018. "Pengaruh Model RMS (Reading, Mind Mapping and Sharing) Terhadap Kemampuan Berpikir Tingkat Tinggi Siswa Pada Pokok Bahasan Implus Dan Momentum." Jurnal Pendidikan Edutama 5 (1): $31-44$.

Fanani, A., and D. Kusmaharti. 2016. "Pengembangan Pembelajaran Berbasis HOTS (High Order Thinking Skill) Di Sekolah Dasar Kelas V.” Jurnal Pendidikan Dasar, 9 (1): 1-11.

Gunawan, G., A. Harjono, and S Sutrio. 2017. "Multimedia Interaktif Dalam Pembelajaran Konsep Listrik Bagi Calon Guru.” Jurnal Pendidikan Fisika Dan Teknolog 1 (9).

Hayati, Sri, Agus Setyo Budi, and Erfan Handoko. 2015. "Pengembangan Media Pembelajaran Flipbook Fisika Untuk Meningkatkan Hasil Belajar Peserta Didik." In Seminar Nasional Jurusan Fisika, Fakultas MIPA Universitas Negeri Jakarta Prosiding Seminar Nasional Fisika (E-Journal). Vol. IV.

Husein, S., L. Herayanti, and Gunawan. 2015. "Pengaruh Penggunaan Multimedia Interaktif Terhadap Penguasaan Konsep Dan Keterampilan Berpikir Kritis Siswa Pada Suhu Dan Kalor.” Jurnal Pendidikan Fisika Dan Teknologi 1 (3): 221-25. 
Irwandani, B Kamil, and D Saraswati. 2019. "Efektivitas Pembelajaran Inkuiri Terbimbing Terhadap Hots Dengan Bantuan Alat Peraga Materi Kalor Dan Perubahannya." Indoneisa Journal of Science and Mathematics Education 3 (1): $1-8$.

P, Pimthong, and J Williaam. 2018. "Preservice Teacher' Understanding of STEM Education." Kasetsart Journal of Social Science 1 (7).

Prasetyo, Kun Zuhdan. 2017. "Pembelajaran Dan Kompetensi Pendidikan Abad 21." Inovasi Pendidikan.

Puspitasari, Reni Dwi, Kartini Herlina, and Agus Suyatna. 2020. "Perception of Physics and Student about E-Module Using STEM- Integrated Flipped Classroom Approach to Improve Critical Thinking Skills." Jurnal Pembelajaran Fisika 8 (1): $1-8$.

Rante, P., Sudarto, and N. Ihsan. 2013. "Pengembangan Multimedia Pembelajaran Fisika Berbasis Audio-Video Eksperimen Listrik Dinamis Di Smp.” Jurnal Pendidikan IPA Indonesia 2 (2).

Roida, Pakpahan, and Fitriani Yuni. 2020. "Analisa Pemanfaatan Teknologi Informasi Dalam Pembelajarann Jarak Jauh Di Tengah Pandemi Virus Corona Covid 19." Journal of Informatiion System, Applied Management, Accountinng and Research 4 (2).

Saregar, Antomi, Sri Latifah, and Meisita Sari. 2016. "Efektivitas Model Pembelajaran Cups: Dampak Terhadap Kemampuan Berpikir Tingkat Tinggi Peserta Didik Madrasah Aliyah Mathla'ul Anwar Gisting Lampung." Jurnal Ilmiah Pendidikan Fisika Al-Biruni 5 (2): 235.

Scott, C.L. 2015. "The Futures of Learning 2: What Kind of Learning for the 21st Century?" Jurnal Unesco Education Research and Foresight 14 (2): 2-7.

Serevina, Vina, and Inayati Juwita Sari. 2018. "Development of E-Module Based on Problem Based Learning (PBL) on Heat and Temperature to Improve Student's Science Process Skill.” Turkish Online Journal of Educational Technology TOJET 17 (3): 27.

Sihaloho, Yuni Evi Meliani, Undang Rosidin, and Agus Suyatna. 8AD. "CBT HOTS Assesment Instrument Model: Teacher Preception Analysis of a Role of Illusstration as Well as Quiz and Question Setting According to HOTS." Jurnal Pembelajaran Fisika 1 (2020): 9-17.

Subekti, Hasan. 2018. "Mengembangkan Literasi Informasi Melalui Belajar Berbasis Kehidupan Terintegrasi STEM Untuk Menyiapkan Calon Guru Sains Dalam Menghadapi Era Revolusi Industri 4.0Revieu Literatur'." Education and Human Development Journal 3 (1): 81-90.

Susanto, B., and A. Suyatna. 2015. "Design Learning Media of Global Warming Based on Interactive Multimedia With Scientific Approach to Critical Thinking Skills." In Proceeding the 3rd SEA-DR Palembang: Universitas Sriwijaya., 325-334. 